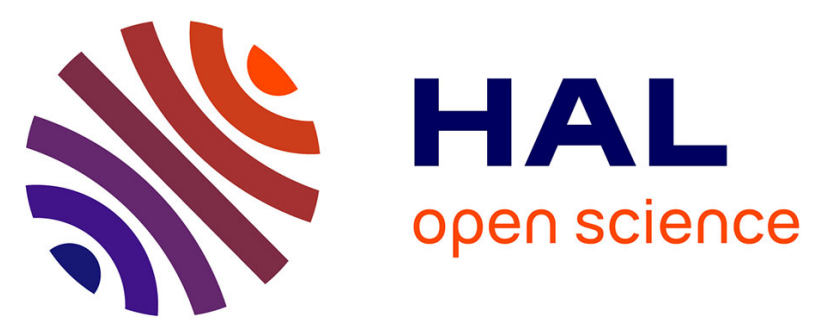

\title{
Feeding choice and predation pressure of two invasive gammarids, Gammarus tigrinus and Dikerogammarus villosus, under increasing temperature
}

Laura Pellan, Vincent Médoc, D Renault, Thierry Spataro, Christophe Piscart

\section{- To cite this version:}

Laura Pellan, Vincent Médoc, D Renault, Thierry Spataro, Christophe Piscart. Feeding choice and predation pressure of two invasive gammarids, Gammarus tigrinus and Dikerogammarus villosus, under increasing temperature. Hydrobiologia, 2016, 781 (1), pp.43-54. 10.1007/s10750-015-2312-3 . hal-01158618

HAL Id: hal-01158618 https://hal-univ-rennes1.archives-ouvertes.fr/hal-01158618

Submitted on 30 Nov 2016

HAL is a multi-disciplinary open access archive for the deposit and dissemination of scientific research documents, whether they are published or not. The documents may come from teaching and research institutions in France or abroad, or from public or private research centers.
L'archive ouverte pluridisciplinaire HAL, est destinée au dépôt et à la diffusion de documents scientifiques de niveau recherche, publiés ou non, émanant des établissements d'enseignement et de recherche français ou étrangers, des laboratoires publics ou privés. 
1 Feeding choice and predation pressure of two invasive gammarids, Gammarus

2 tigrinus and Dikerogammarus villosus, under increasing temperature

3

4 Laura Pellan ${ }^{1} \bullet$ Vincent Médoc $^{2} \bullet$ David Renault $^{1} \cdot$ Thierry Spataro $^{2} \cdot$ Christophe Piscart $^{1, *}$ 5

$6 \quad{ }^{1}$ UMR CNRS 6553 Ecosystèmes, Biodiversité, Evolution, (ECOBIO); Université Rennes 1; 263 avenue 7 du Général Leclerc, 35042, Rennes Cedex, France.

8

$9{ }^{2}$ UMR Institut d'Ecologie et des Sciences de l'Environnement de Paris

10 Université Pierre et Marie Curie (Paris 6), 7 quai Saint Bernard, 75252, Paris cedex 05, France.

11

12 *Corresponding author: Piscart C., christophe.piscart@univ-rennes1.fr

13

14

15 A running headline: Temperature effects on the diet of invasive gammarids

16 


\section{Abstract}

18 In most European freshwater ecosystems, the invasive gammarids Gammarus tigrinus and Dikerogammarus villosus strongly impair recipient communities through predation of a wide range of native invertebrates. Due to the effects of temperature on both the physiology and the behaviour of such ectotherms, understanding how global warming may influences their ecological impact is a research priority. These species were therefore exposed to three different food types to determine their detritivorous, herbivorous and carnivorous characters, and predation was measured characterizing the Holling's functional response. The effect of increasing water temperatures $\left(15,20,25^{\circ} \mathrm{C}\right)$ on both the food choice and predatory activities was investigated. Both species showed a significant preference for animal tissues at all temperatures. The total food intake increased with temperature for $G$. tigrinus but did not change for $D$. villosus, which may result from specific-species differences in metabolic requirements. The consumption of live prey strongly increased with temperature. The main differences were an increased searching efficiency in G. tigrinus and a decreased handling time in D. villosus as temperature increased, which may result from differences in foraging strategies. These results suggest that climate change is likely to increase the predation pressure of both invasive gammarids on prey species. 
In the past few decades, the establishment of invasive species has strongly disturbed the structure and function of many freshwater ecosystems (Ricciardi \& MacIsaac, 2011). Although environmental factors are known to play a crucial role in the spread of many non-native invasive species (Leppäkoski et al., 2002; Labat et al., 2011), little is known about their influence on the nature and direction of species' ecological impacts (Van der Velde et al., 2009). In addition, the strength of ecological impact is a growing concern in the context of current global changes (Bellard et al., 2013), as the resulting changes in environmental conditions (e.g. nutrient concentrations, temperature, pollution) could significantly alter the competitive balance between alien and native species (Piscart et al., 2009). The scenarios of the Intergovernmental Panel on Climate Change (IPCC) predict a global increase in temperature from For these ectothermic organisms, even a minor increase in temperature may strongly influence both physiology and behaviour (Maazouzi et al., 2011; Foucreau et al., 2014; Colinet et al., 2015). The success of most invasive aquatic crustaceans correlates with their strong capacity to tolerate environmental stressors and/or the flexibility of their diet (Van der Velde et al., 2000). Consequently, the changes in temperature predicted by the IPCC could influence the establishment of aquatic invasive species, and could modulate their impacts on recipient ecosystems (Rahel \& Olden, 2008). The invasive gammarids (Crustacea: Amphipoda) Gammarus tigrinus Sexton 1939 and (e.g. ability to exploit trophic resources: Van der Velde et al., 2000; Maazouzi et al., 2009; their tolerance of a wide range of environmental factors: Wijnhoven et al., 2003; Piscart et al., 2011a), these 
and at high rates. For instance, the functional response (the relationship between resource use and resource availability) (Holling, 1959a), has been shown to rise more steeply and to a higher asymptote than in native gammarids (Bollache et al., 2008; Dick et al., 2013). D. villosus is known to have a higher searching efficiency and a lower handling time than its native counterparts, and was therefore more efficient in exploiting trophic resources. As such, invasive gammarids may strongly affect the structure and functioning of recipient ecosystems (Bollache et al., 2004; Orav-Kotta et al., 2009; Piscart et al., 2010, 2011b). The North American amphipod G. tigrinus is a thermophilous species capable of tolerating temperatures of up to ca. $32{ }^{\circ} \mathrm{C}$ (Wijnhoven et al., 2003). In contrast, the Ponto-Caspian $D$. villosus prefers cooler temperatures, but its sedentary lifestyle allows it to maintain a lower basal metabolic rate than its native relatives, as well as high predation rates when temperature exceeds $25{ }^{\circ} \mathrm{C}$ (Maazouzi et al., 2011). Thermal plasticity involves physiological modifications within individuals, which increase energy requirements (Pörtner et al., 2002; Issartel et al., 2005a; 2005b; Maazouzi et al., 2011). G. tigrinus and D. villosus must therefore satisfy increased energy needs if they are to persist in the habitats exposed to increasing temperatures. In many aquatic ectotherms, the energetic cost resulting from increasing temperature is compensated by dietary shifts. These changes may be quantitative, with previous studies reporting increased food intake in aquatic ectotherms (Niu et al., 2003; Van der Velde et al., 2009; Woodward et al., 2010), and/or qualitative, with consumers relying increasingly on highenergy food sources such as animal tissues, when exposed to increasing water temperatures (Parmenter, 1980).

Gammarids are opportunistic feeders capable of switching their trophic regime from herbivorous (Dehedin et al., 2013) to detritivorous (Piscart et al. 2011b) and carnivorous (Piscart et al. 2009) components with the consumption of dead or live prey (MacNeil et al., 1997). In the context of temperature increases, the main hypothesis of this study was that G. tigrinus and D. villosus will prioritize carnivory, which provide more energy, and increase their overall food intake, therefore increasing predation pressure on resident prey populations (e.g., other crustacean species). The primary 
aim of this study was to detect quantitative and qualitative changes in the diet of $G$. tigrinus and $D$. villosus exposed to a range of thermal conditions. In this context, we predicted: (i) an increase in the overall quantity of food consumed as temperature increased (ii) a concomitant growing preference for animal tissues. To validate predictions (i) and (ii), food choice experiments were performed, with both species were offered macrophytes, leaf litter and dead chironomid larvae at three different water temperatures $\left(15,20\right.$ and $\left.25{ }^{\circ} \mathrm{C}\right)$. We also predicted (iii) that increasing temperature would enhance the predatory activity of invasive gammarids, thus amplifying their impacts on prey. To examine this prediction, a second experiment was conducted to determine the functional response (FR) of G. tigrinus and $D$. villosus fed on live water fleas under the three different temperatures. We hence predicted that FR parameters (i.e. searching efficiency and handling time) should be modified by increasing temperature, with the per capita predation rate increasing more steeply and to a higher asymptote.

\section{Materials and methods}

\section{Specimen collection and maintenance}

Experiments were performed with specimens collected by kick sampling from the Brivet River near Saint Nazaire $\left(47^{\circ} 19^{\prime} 21.0822^{\prime \prime}\right.$ N, $\left.2^{\circ} 11^{\prime} 41.9136 " \mathrm{~W}\right)$ from February 2014 to March 2014 for $G$. tigrinus, and from the Loire River near Bourgeuil (47¹4'10.83" N, 09'2.18"E) in April 2014 for $D$. villosus. The two sites, approx. $180 \mathrm{~km}$ apart, have been inhabited by invasive species for at least the last decade (Piscart et al., 2010) and experience the same climatic conditions. To avoid any body size effect, only adult males and females with intermediate size ranges (8-12 mm for G. tigrinus and 12-16 $\mathrm{mm}$ for $D$. villosus) were used. Given that adults do not exhibit a distinct sexual dimorphism except when females are ovigerous, they were captured during the precopula mate guarding period and carefully separated in the field. Conversely, D. villosus exhibit a distinct sexual dimorphism (males having more robust gnathopods than females and the second antenna have dense 'brush-like' tufts of setae (Piscart \& Bollache, 2012) and were captured at any conditions. Since parasite infection can 
111 modify gammarids' FR (Dick et al., 2010), those harbouring symptomatic parasites such as

112 acanthocephalans and muscle-wasting microsporidians (when distinguishable) were excluded. Sampled

113 organisms were then transferred to controlled conditions. The two species were maintained separately at

$11415{ }^{\circ} \mathrm{C}$ in 10 -L tanks filled with aerated site water under a 12:12 h light:dark. Animals were fed $\mathrm{ad}$

115 libitum with vegetation and fauna from the sampling sites, except during the starvation period (see

116 below).

\section{Experiment 1-food choice according to temperature}

119 The consumption of different food types by G. tigrinus and D. villosus was monitored at three water

120 temperatures: $15^{\circ} \mathrm{C}$, corresponding to the thermal optimum for both species (Wijnhoven et al., 2003;

121 Maazouzi et al., 2011); $20{ }^{\circ} \mathrm{C}$, the mean temperature often observed at the sampling sites in summer

122 (DREAL Bretagne, 2014); and $25^{\circ} \mathrm{C}$, to simulate the $5{ }^{\circ} \mathrm{C}$ increase in temperature predicted by the IPCC (2013) worst-case scenario.

We used three diets to encompass the various feeding modes used by gammarids: herbivory with fresh macrophytes (Apium nodiflorum (L.) Lag. 1821) collected from the Yaigne River (Vern-sur-Seiche, Bretagne, $49^{\circ} 02^{\prime} 03.9^{\prime \prime} \mathrm{N}, 1^{\circ} 34^{\prime} 08.0^{\prime \prime} \mathrm{W}$ ); detritivory with conditioned leaf litter (Corylus avellana (L.) 1753) also collected from the Yaigne; and carnivory with thawed dead dipteran larvae (Chironomus riparius (Meigen, 1804)). We used dead chironomids to exclude the energetic cost of capturing live prey, which could hide a potential shift towards carnivory under the assumption of temperature-induced

130 changes in energy needs.

Prior to experimentation at 20 and $25{ }^{\circ} \mathrm{C}$, gammarids were acclimatized to the experimental temperature for $24 \mathrm{~h}$, by gradually increasing the temperature in one degree steps from $15{ }^{\circ} \mathrm{C}$ to the required temperature (Foucreau et al., 2014). After the temperature acclimatization period, gammarids

134 starved individually for $24 \mathrm{~h}$ without food, to increase appetite and reduce food residue in the gut

135 (standardization of hunger). We check that no cannibalism appear by counting the 
After $48 \mathrm{~h}$ (i.e. $24 \mathrm{~h}$ of acclimatization and $24 \mathrm{~h}$ of starvation), 20 gammarids (10 males and 10

137 females) of each species were placed into separate 20-cm diameter glass petri dishes filled with $180 \mathrm{~mL}$

138 filtered water from the sampling sites for $48 \mathrm{~h}$, under a 12:12 h light:dark regime. This duration was

139 considered short enough to avoid any effect of thermal conditions on food (e.g. macrophyte necrosis

140 macrophyte at higher temperatures) and long enough to take into account temporal variation in food

141 consumption (Piscart et al., 2011b). Daily measures of dissolved oxygen concentrations were realized

142 randomly in petri dishes to be sure that no oxygen depletion occurred during the experiment, especially

143 at high temperatures. Five 6-mm diameter macrophyte discs, five 6-mm diameter leaf litter discs, and 15

144 chironomid larvae were randomly placed into each petri dish. As a result, each food type covered a

145 similar area of the petri dish. To avoid food depletion, partially or entirely consumed leaf discs or larvae

146 were replaced $24 \mathrm{~h}$ after the beginning of the experiment. For each temperature, three control treatments

147 consisting of a petri dish filled with water and the three food types but without gammarids were

148 performed to estimate food consumption related to bacterial and fungal activities.

149 The fresh weight of each food type was measured before and after the experiment (Ohaus®

150 Analytical Plus balance, Ohaus AP250D) to estimate the quantity (Qi) of the food type (i) that was

151 consumed per mg of gammarid after $48 \mathrm{~h}$, as follows:

$152 \mathrm{Qi}=(\mathrm{MFi}-\mathrm{MIi})-\mathrm{Di}$

153 Where (MIi) and (MFi) are the fresh weights of the food type (i) at the beginning and at the end of the

154 experiment, respectively, and (Di) is the mean difference in fresh weight before and after the experiment 155 in the control treatments.

156 The food preference of gammarids was assessed by measuring the index of relative importance

157 (IOI) of each food type (i) as follows (modified version of Kurian, 1977):

$158 \quad \mathrm{IOIi}=(100 \times \mathrm{Qi}) / \mathrm{Q}$

159 Where (Q) is the total quantity of food consumed per mg of gammarid over $48 \mathrm{~h}$. 
162 The functional response of G. tigrinus and D. villosus fed on water fleas (Simocephalus exspinosus (De

163 Geer, 1778)) at 15,20 and $25^{\circ} \mathrm{C}$ was determined. The prey were entirely consumed by gammarids

164 during this experiment, facilitating prey counting and the calculation of predation rates (Stoffels et al., 165 2011).

166 Water fleas were collected from a pond located on the campus of the University of Rennes 1 (campus de 167 Beaulieu, Rennes, France) $\left(48^{\circ} 07^{\prime} 08.0^{\prime \prime} \mathrm{N}, 1^{\circ} 38^{\prime} 22.1^{\prime \prime}\right)$. Gammarids and prey were gradually 168 acclimatized to the temperature of 20 or $25{ }^{\circ} \mathrm{C}$ over $24 \mathrm{~h}$ as for the experiment 1 . After this 169 acclimatization period, gammarids were starved for $24 \mathrm{~h}$.

After $48 \mathrm{~h}$ (i.e. $24 \mathrm{~h}$ of acclimatization and $24 \mathrm{~h}$ of starvation), gammarids were placed into

171 individual plastic cups (7 cm diameter) filled with $60 \mathrm{~mL}$ of filtered water from their sampling site and

172 containing $1,3,6,12,18$ or 24 water fleas (prey density, $N$ ), without shelter for prey or gammarids. The

173 duration of the experiment was $8 \mathrm{~h}$ based on preliminary tests and consumed prey were continuously 174 counted and replaced immediately following consumption, to avoid prey depletion. For each 175 temperature, prey density and gammarid species were replicated with three males and three females, 176 giving a total of 216 predation tests. Six replicates of each prey density but without gammarids were 177 used to control for prey mortality.

Statistical analyses

180 The total quantity of food consumed by gammarids exposed to the different temperatures was compared 181 using analyses of variance (ANOVA) tests, with temperature and sex as fixed factors. Data were log- or 182 square root- transformed to meet assumptions of homoscedasticity and normality. Pairwise comparisons 183 between temperatures were performed using Tukey's HSD tests. The respective contribution of each 184 food type, represented by the index of relative importance (IOI), was compared for the different 185 temperatures using ANOVA models. Since the transformed values of IOI did not meet the normality 
assumption, Friedman's tests were used to check for significant differences in IOI values between the food types for each temperature. Pairwise comparisons were then performed using Wilcoxon signed rank tests. Kruskal-Wallis tests were performed to identify differences between the IOI values among temperatures for each food type. Pairwise comparisons were then conducted using Wilcoxon signed rank tests.

FR parameters, namely predator searching efficiency and prey handling time, were estimated by fitting the observed predation rates to the Holling's type II FR model (Holling, 1959b):

$$
\mathrm{g}(N)=a N /(1+a h N)
$$

where $g(N)$ is the per capita predation rate, $N$ is the prey density, $a$ is a measure of the searching efficiency and $h$ is the handling time.

Non-linear regressions were performed with the $n l s$ function of R software (R Development Core Team 2010). Confidence intervals of the parameter estimates were obtained using a bootstrap method applied to residuals, to avoid making a normality assumption.

To test the influence of increasing temperature on gammarid FR, FR parameter estimates obtained at each temperature were compared with a backward and forward stepwise model selection procedure designated as Dynamics Likelihood Ratio Tests by Posada and Crandall (2001). A set of models including the simplest model assuming the same parameter values for all temperatures (two parameters), the most complex model assuming different parameter values per temperature (six parameters) and all intermediate models was considered and the following forward/backward procedures were applied:

1. Start from the simplest/most complex model. This is the current model.

2. Consider all the alternative models with one additional/less parameter.

3. Select the alternative model that leads to the greater decrease/smaller increase of the residual sum of squares (RSS).

4. Compare the current model and the selected model using a likelihood ratio test. 

the selected model as the current model.

In addition, the confidence regions (Beale, 1960) for the parameter estimates when the three FRs per gammarid species were considered separately were constructed and represented. These confidence regions were defined as the set of parameter values such that the RSS stays below a given threshold:

$$
R S S(\theta)<R S S_{\min }\left[1+p /(n-p) F_{1-\alpha}(p, n-p)\right]
$$

All statistical analyses were performed using R 3.1.0 software.

\section{Results}

\section{Experiment 1 - food choice according to temperature}

For G. tigrinus, sex factor had a significant effect on the quantity of food consumed by gammarid

(ANOVA, $\mathrm{F}_{53,1}=24.05 ; p<0.001$ ), and females consumed a greater quantity of food than males at 20 and $25^{\circ} \mathrm{C}$ (Tukey's HSD test, $p<0.05$, Fig. 1a). Moreover, the total quantity of food consumed by $G$. tigrinus increased with temperature (ANOVA, $\mathrm{F}_{53,2}=40.86 ; p<0.001$, Fig. 1a). The food intake was two to three times higher at 20 or $25^{\circ} \mathrm{C}$ than at $15{ }^{\circ} \mathrm{C}$, for both sexes (Tukey's HSD test, $p<0.05$, Fig. 1a). For D. villosus, sex had no significant effect on the quantity of food consumed with respect to temperature (ANOVA, $\mathrm{F}_{50,1}=1.61 ; p=0.21$ ), except at $25^{\circ} \mathrm{C}$ where the females consumed more food than the males (Tukey's HSD test, $p<0.05$, Fig. 1b). In contrast to G. tigrinus, the food intake for $D$. villosus was not influenced by temperature (ANOVA, $\mathrm{F}_{53,2}=2.67 ; p=0.08$, Fig. $1 \mathrm{~b}$ ). The total quantity of food consumed by D. villosus was the same at all temperatures $(23.38 \pm 6.46 \mathrm{mg}$ of food per $\mathrm{mg}$ of gammarid for females and $18.22 \pm 5.64 \mathrm{mg}$ of food per $\mathrm{mg}$ of gammarid for males).

All food types were consumed by both species, and both preferentially consumed chironomid 233 larvae at all three temperatures (Friedman's test, $p<0.001$, Fig. 2). The IOI of macrophytes was 234 significantly higher at 20 and $25^{\circ} \mathrm{C}$ than at $15{ }^{\circ} \mathrm{C}$ for $G$. tigrinus (Kruskal-Wallis test, $\chi^{2}=36.38 ; \mathrm{df}=2$; $p<0.001$, Fig. 2a), whereas the opposite pattern was observed for the IOI of chironomid larvae 
236 (Kruskal-Wallis test, $\chi^{2}=29.30 ; \mathrm{df}=2 ; p<0.001$, Fig. 2a). For D. villosus, the IOI of macrophytes was 237 significantly higher at $20^{\circ} \mathrm{C}$ than at 15 and $25^{\circ} \mathrm{C}$ (Kruskal-Wallis test, $\chi^{2}=25.24 ; \mathrm{df}=2 ; p<0.001$, Fig. 238 2b).

\section{Experiment 2 - functional response according to temperature}

241 Prey showed no mortality in the control treatments, suggesting that deaths during the experiments were 242 due to gammarid predation only. The plot of the consumption rate as a function of prey density (Fig. 3) showed an increasing but decelerating relationship for each temperature and each gammarid species, supporting the assumption of a type II FR. However, the shape of these relationships seemed different according to the temperature and the gammarid species, suggesting an impact of these factors on the FR 246 parameter values. The fits of the Holling's type II FR model to the data are also shown in Fig. 3, while 247 the corresponding parameter estimates and their $95 \%$ confidence intervals are detailed in Table 1. 248 Regardless of the gammarid species, both the backward and forward dynamics likelihood ratio test 249 procedures converged to the same alternative model (Fig. 4). For G. tigrinus, an alternative model with 250 five parameters was retained (Fig. 4a). The searching efficiency $a$ was equivalent between 15 and $20^{\circ} \mathrm{C}$, 251 and was significantly higher at $25{ }^{\circ} \mathrm{C}$ (see Fig. 4a for the results of the stepwise procedure and the 252 associated statistics: LRT p-values and $\mathrm{AIC}_{\mathrm{c}}$ values). The handling time $h$ was highest at $15{ }^{\circ} \mathrm{C}$ and 253 increased between 20 and $25{ }^{\circ} \mathrm{C}$ (Fig. 4a, Table 1). For D. villosus, an alternative model with four 254 parameters was retained (Fig. 4b). The searching efficiency was significantly higher at $20{ }^{\circ} \mathrm{C}$ and did not differ between 15 and $25{ }^{\circ} \mathrm{C}$ (see Fig. $4 \mathrm{~b}$ for the results of the stepwise procedure and the associated 256 statistics). The handling time was equivalent between 15 and $20{ }^{\circ} \mathrm{C}$, and significantly decreased at $25^{\circ} \mathrm{C}$ 257 (Fig. 4b, Table 1). For G. tigrinus, the projections of the confidence regions showed little overlap on the $258 \mathrm{y}$-axis suggesting three distinct values of handling time, and a strong overlap only between 15 and $20{ }^{\circ} \mathrm{C}$ on the $\mathrm{x}$-axis suggesting a higher searching efficiency at $25^{\circ} \mathrm{C}$ (Fig. 5a). For D. villosus, only the value 
of the handling time at $25{ }^{\circ} \mathrm{C}$ differed from the others on the y-axis, and only the value of the searching

261 efficiency at $20^{\circ} \mathrm{C}$ differed from the others on the x-axis (Fig. 5b).

\section{Discussion}

Our results clearly highlighted that temperature significantly alters the feeding behaviour of invasive gammarids (Van der Velde et al., 2009); probably because thermal tolerance increases energy needs (Wijnhoven et al., 2003; Maazouzi et al., 2011; Foucreau et al., 2014).

\section{Experiment 1 - food choice according to temperature}

270 Consistent with their omnivorous status (Poje et al., 1988; Platvoet et al., 2009b), all food types 271 provided were consumed by both species during the experiments. The effect of sex on food intake of $G$. tigrinus, and to a lesser extent $D$. villosus, may be explained by differences in energy metabolism among sexes (Foucreau et al., 2013). Energy requirements are higher for females than males due to their more energy-expensive reproductive cycle (Sutcliffe, 2010) and their higher metabolic rate related to their lower body weight (Normant et al., 2007). These differences in energy metabolism coupled to the energetic demand under increasing temperature might explain the higher food consumption observed in females at $20{ }^{\circ} \mathrm{C}$ and/or $25{ }^{\circ} \mathrm{C}$. At $15{ }^{\circ} \mathrm{C}$, the total quantity of food ingested by G. tigrinus was twice as high as that consumed by D. villosus, suggesting that G. tigrinus is more voracious than D. villosus.

Moreover, the total quantity of food consumed per mg of gammarid increased with temperature in G. tigrinus but not in D. villosus. The first prediction suggesting a positive effect of temperature on

281 the quantity of food consumed by gammarids was confirmed only for G. tigrinus. Compared to $G$. 282 tigrinus, which exhibits a considerable swimming activity (personal observation), D. villosus is an 283 ambush predator that stays motionless (Platvoet et al., 2009b), and whose swimming activity is low and 284 not influenced by increasing temperature (Maazouzi et al., 2011). In addition, previous studies have 
highlighted that $D$. villosus has a lower basal metabolism than many other amphipods (Wijnhoven et al.,

286 2003; Maazouzi et al., 2011). The behaviour and the lower metabolic rate of D. villosus hence require

287 less energy compared to G. tigrinus at high temperature. Therefore, D. villosus, compared to G. tigrinus, needs less energy to significantly increase food intake. In addition, the non-linear relationship that exists between temperature and performance in ectotherms may result in differential effects of any thermal increase if the performance curves of the species do not perfectly overlap (Colinet et al., 2015). $G$. tigrinus is a thermophilous species (Wijnhoven et al., 2003), and may therefore exhibit a more pronounced response to thermal changes due to a high amplitude of its thermal performance curve. However, additional experiments with measurements of the metabolic rates and swimming activities of gammarids are needed to confirm this hypothesis.

Contrary to the second prediction, food preferences did not changed significantly with increasing temperature. The proportion of each food type varied only slightly with an important consumption of dead chironomids. This is not surprising as dead chironomids were the most energy-rich food source in this study. This result is consistent with previous investigations (MacNeil \& Platvoet, 2005; Platvoet et al., 2009a; Van der Velde et al., 2009), and confirms the high level of carnivory of these invasive gammarids. However, the overconsumption of dead prey under laboratory conditions does not mean that gammarids are strong predators in nature. For instance, Médoc et al. (2011) found that the consumption of isopods (Asellus aquaticus) by Gammarus roeseli was significantly reduced when the prey were alive. Additional food-choice experiments are needed to test whether the cost of capturing live prey changes gammarids' food preferences.

Maximum consumption of macrophytes was observed at $20{ }^{\circ} \mathrm{C}$ in both species, and also at $25{ }^{\circ} \mathrm{C}$ in G. tigrinus. These results might be due to the macrophyte discs floating and therefore constituting a 307 food resource as well as a habitat for the gammarids, while chironomid larvae and leaf litter remained at 308 the bottom of the experimental units. The gammarids appeared less mobile under high temperature and could increase the time spent on substrates that can be eaten to save energy, which might explain the 
growing contribution of floating macrophytes to the diet. Another explanation might be that with

311 increasing temperature, increase in both epilithic biofilm production and microbial decomposition of the leaves made them more palatable to the gammarids (Díaz Villanueva et al., 2011a,b).

\section{Experiment 2 - functional response}

315 The number of prey consumed increased with water temperature in both species, which agrees with the

316 third prediction and the results of previous studies (Van der Velde et al., 2009; Maier et al., 2011;

317 Stoffels et al., 2011). These data seem not congruent with the total food intake of $D$. villosus, observed

318 in the first experiment, which did not increase with temperature over $48 \mathrm{~h}$. However, the first

319 experiment was conducted with dead chironomids, whereas D. villosus is known to be aggressive (Dick

320 et al., 2002), and its attacks on live prey may have increased with its increased activity. Significant

321 differences in FR parameters were observed among temperatures. Searching efficiency increased with

322 temperature and was highest at $25{ }^{\circ} \mathrm{C}$ for G. tigrinus and at $20{ }^{\circ} \mathrm{C}$ for D. villosus. The searching

323 efficiency of $D$. villosus was hence maximal at the intermediate temperature $\left(20^{\circ} \mathrm{C}\right)$ and not at the

324 highest temperature $\left(25^{\circ} \mathrm{C}\right)$ as for G. tigrinus. These results may be due to differences in the foraging

325 strategy of the two gammarids. Prey mobility might have increased with temperature (Gerritsen, 1982),

326 thereby promoting predator-prey encounters and explaining the increase in searching efficiency between

32715 and $20^{\circ} \mathrm{C}$. Beyond a given level of prey mobility, the ambush predator might be expected to become

328 less successful in catching prey, which could explain the decrease in searching efficiency between 20

329 and $25{ }^{\circ} \mathrm{C}$ for D. villosus. Alternatively, D. villosus, which has a more restricted thermal plasticity than

330 G. tigrinus, is likely to be more stressed at $25{ }^{\circ} \mathrm{C}$ and its efficiency could be reduced by the stressful

331 thermal conditions (Stoffels et al., 2011).

332 For both species, the handling time decreased with temperature and was the lowest at $20{ }^{\circ} \mathrm{C}$ for

333 G. tigrinus and at $25^{\circ} \mathrm{C}$ for $D$. villosus. Gammarids probably displayed a stronger predatory behaviour

334 with reduced handling times and quicker intakes to forage more and satisfy the temperature-induced 
335 increase in energetic needs. G. tigrinus is much smaller than D. villosus, and therefore probably less

336 successful in handling mobile prey. This could explain the increase in the handling time of G. tigrinus

337 between 20 and $25^{\circ} \mathrm{C}$ when prey mobility was expected to be highest.

Conclusion

340 To conclude, no evidence was found on for a qualitative change in the diet of G. tigrinus and D. villosus

341 under increasing temperature, with a preference for animal tissues regardless of the experimental

342 temperature. However, the food intake increased with temperature, suggesting that predation pressure by

343 both invasive species on resident prey is likely to increase with ongoing global warming, with slight

344 differences depending on the foraging strategy. G. tigrinus actively forages and its searching efficiency

345 increased with temperature, causing potential impacts at low prey densities. D. villosus is an ambush

346 predator whose handling time decreased with temperature, causing potential impacts at high prey

347 densities. Due to its predatory behaviour and aggressiveness, D. villosus receives much attention

348 compared to other invasive species such as G. tigrinus (Dick \& Platvoet, 2000; Dick et al., 2002;

349 MacNeil \& Platvoet, 2005; MacNeil et al., 2010). Although D. villosus is a large predator capable of

350 consuming more prey than G. tigrinus, the total quantity of food consumed by G. tigrinus was three

351 times that of $D$. villosus at $25{ }^{\circ} \mathrm{C}$ when considering equivalent biomass. In this way, the dietary response

352 of G. tigrinus to increasing temperature can be viewed as more pronounced than that of D. villosus. Ours

353 study hence suggests that global warming needs to be carefully considered in the study of biological

354 invasions. Global warming is a factor that could strongly strengthen the impact of invasive species on

355 native fauna and also modify the relative impact of the different invasive species. 
359 helping us during the collection of gammarids. We greatly thank anonymous referees for helpful 360 comments and advice concerning an earlier version of this paper.

361 


\section{References}

363 Bellard, C., W. Thuiller, B. Leroy, P. Genovesi, M. Bakkenes \& F. Courchamp, 2013. Will climate change promote future invasions? Global Change Biology 19: 3740[3748.

Bollache, L., S. Devin, R. Wattier, M. Chovet, J. N. Beisel, J. C. Moreteau \& T. Rigaud, 2004. Rapid range extension of the Ponto-Caspian amphipod Dikerogammarus villosus in France: potential consequences. Archiv für Hydrobiologie 160: 57】66.

Bollache, L., J. T. A. Dick, D. K. Farnsworth \& I. W. Montgomery, 2008. Comparison of the functional responses of invasive and native amphipods. Biology Letters 4: 166】169.

Colinet, H., B. J. Sinclair P. Vernon \& D. Renault, 2015. Insects in fluctuating thermal environments. Annual Review of Entomology 60: 7.1[7.18.

372

Cruz-Rivera, E. \& M. E. Hay, 2000. Can quantity replace quality? Food choice, compensatory feeding, and fitness of marine mesograzers. Ecology 81: 201[219.

Dehedin, A., C. Maazouzi, S. Puijalon, P. Marmonier \& C. Piscart, 2013. Combined effects of the water level reduction and the increase in ammonia concentrations on organic matter processing by key freshwater shredders in alluvial wetlands. Global Change Biology 19: 763-774

Díaz Villanueva, V., R. Albariño \& C. Canhoto, 2011a. Detritivores feeding on poor quality food are more sensitive to increased temperatures. Hydrobiologia 678: 155】165.

Díaz Villanueva, V., J. Font, T. Schwartz \& A. M. Romaní, 2011b. Biofilm formation at warming temperature: acceleration of microbial colonization and microbial interactive effects. Biofouling 27: 59-71.

Dick, J. T. A. \& D. Platvoet, 1996. Intraguild predation and species exclusions in amphipods: the interaction of behaviour, physiology and environment. Freshwater Biology 36: 375】383.

Dick, J. T. A. \& D. Platvoet, 2000. Invading predatory crustacean Dikerogammarus villosus eliminates both native and exotic species. Proceedings of the Royal Society of London B 267: 977[983. 
Dick, J. T. A., D. Platvoet, \& D. W. Kelly, 2002. Predatory impact of the freshwater invader Dikerogammarus villosus (Crustacea: Amphipoda). Canadian Journal of Fisheries and Aquatic Sciences 59: 1078】1084.

Dick, J. T. A., M. Armstrong, H. C. Clarke, K. D. Farnsworth, M. J. Hatcher, \& M. Ennis, 2010. Parasitism may enhance rather than reduce the predatory impact of an invader. Biology Letters 6: $636 \square 638$.

Dick, J. T. A., K. Gallagher, S. Avlijas, H. C. Clarke, S. E. Lewis, S. Leung \& A. Ricciardi, 2013. Ecological impacts of an invasive predator explained and predicted by comparative functional responses. Biological Invasions 15: 837[846.

D.R.E.A.L. Bretagne, 2014. Direction Régionale de l'Environnement, de l'Aménagement et du Logement. http://www.bretagne.developpement-durable.gouv.fr/eau

Foucreau, N., C. Piscart, S. Puijalon \& F. Hervant, 2013. Effect of Climate-Related Change in Vegetation on Leaf Litter Consumption and Energy Storage by Gammarus pulex from Continental or Mediterranean Populations. PloS one 8: e77242.

Foucreau, N., D. Cottin, C. Piscart \& F. Hervant, 2014. Physiological and metabolic responses to rising temperature in Gammarus pulex populations (Crustacea) living under continental or Mediterranean climates. Comparative Biochemistry and Physiology (A) 168: 69】75.

Gerritsen, J., 1982. Behavioral Response of Daphnia to Rate of Temperature Change: Possible Enhancement of Vertical Migration. Limnology and Oceanography 27: 254】261.

Holling, C. S., 1959a. The components of predation as revealed by a study of small-mammal predation of the European pine sawfly. The Canadian Entomologist 91: 293[320. Entomologist 91: $385 \square 398$. 
IPCC, 2013. Summary for Policymakers. The Physical Science Basis. Contribution of Working Group I to the Fifth Assessment Report of the Intergovernmental Panel on Climate Change. In: Stocker, T. F., D. Qin, G. K. Plattner, M. Tignor, S. K. Allen, J. Boschung, A. Nauels, Y. Xia, V. Bex \& P. M. Midgley (eds), Climate Change 2013. Cambridge University Press, Cambridge, United Kingdom and New York, NY, USA.

Issartel, J., F. Hervant, Y. Voituron, D. Renault \& P. Vernon, 2005a. Behavioural, ventilatory and respiratory responses of epigean and hypogean crustaceans to different temperatures. Comparative Biochemistry and Physiology (A) 141: 107.

Issartel, J., D. Renault, Y. Voituron, P. Vernon, \& F. Hervant, 2005b. Metabolic responses to cold in subterranean crustaceans. Journal of Experimental Biology 208: 2923】2929.

Kurian, A., 1977. Index of relative importance $\square$ A new method for assessing the food habits of fishes. Indian Journal of Fisheries 24: 217】219.

Labat, F., C. Piscart \& B. Fontan, 2011. First records, pathways and distributions of four new PontoCaspian amphipods in France. Limnologica 41: 290】295.

Leppäkoski, E., S. Gollasch \& S. Olenin, 2002. Invasive aquatic species of Europe: distribution, impacts and management. Springer, Dordrecht.

Maazouzi C., C. Piscart, J. C. Pihan G. Masson, 2009. Effect of habitat-related resources on fatty acid composition and body weight of the invasive Dikerogammarus villosus in an artificial reservoir. Fundamental and Applied Limnology 175: 327】338.

Maazouzi, C., C. Piscart, F. Legier \& F. Hervant, 2011. Ecophysiological responses to temperature of the "killer shrimp" Dikerogammarus villosus: is the invader really stronger than the native Gammarus pulex? Comparative Biochemistry and Physiology (A) 159: $268 \square 274$. 
MacNeil, C., J. T. A. Dick \& R. W. Elwood, 1997. The trophic ecology of freshwater Gammarus spp. (Crustacea: Amphipoda): problems and perspectives concerning the functional feeding group concept. Biological Reviews of the Cambridge Philosophical Society 72: 349】364.

MacNeil, C. \& D. Platvoet, 2005. The predatory impact of the freshwater invader Dikerogammarus villosus on native Gammarus pulex (Crustacea: Amphipoda); influences of differential microdistribution and food resources. Journal of Zoology 267: 31[38.

Maier, G., A. Kley, Y. Schank, M. Maier, G. Mayer \& D. Waloszek, 2011. Density and temperature dependent feeding rates in an established and an alien freshwater gammarid fed on chironomid larvae. Journal of Limnology 70: 123[128.

Médoc, V., C. Piscart, C. Maazouzi, L. Simon \& J. N. Beisel, 2011. Parasite-induced changes in the diet of a freshwater amphipod: field and laboratory evidence. Parasitology 138: 537[546.

Niu, C., D. Lee, S. Goshima \& S. Nakao, 2003. Effects of temperature on food consumption, growth and oxygen consumption of freshwater prawn Macrobrachium rosenbergii (de Man 1879) postlarvae. Aquaculture Research 34: 501】506.

Normant, M., M. Feike, A. Szaniawska \& G. Graf, 2007. Adaptation of Gammarus tigrinus Sexton, 1939 to new environments-Some metabolic investigations. Thermochimica acta 458: 107】111.

Orav-Kotta, H., J. Kotta, K. Herkül, I. Kotta \& T. Paalme, 2009. Seasonal variability in the grazing potential of the invasive amphipod Gammarus tigrinus and the native amphipod Gammarus salinus (Amphipoda: Crustacea) in the northern Baltic Sea. Biological Invasions 11: 597[608.

Parmenter, R. R., 1980. Effects of food availability and water temperature on the feeding ecology of pond sliders (Chrysemys s. scripta). Copeia 3: 503П514. 
Pinkster, S., H. Smit \& N. Brandse-de Jong, 1977. The introduction of the alien amphipod Gammarus tigrinus Sexton, 1939, in the Netherlands and its competition with indigenous species. Crustaceana Supplement 4: 91D105.

Piscart, C., J. T. A. Dick, D. McCrisken \& C. MacNeil, 2009. Environmental mediation of intraguild predation between the freshwater invader Gammarus pulex and the native G. duebeni celticus. Biological Invasions 11: 2141D2145.

Piscart, C., B. Bergerot, P. Laffaille \& P. Marmonier, 2010. Are amphipod invaders a threat to regional biodiversity? Biological Invasions 12: 853-863.

Piscart, C. \& L. Bollache, 2012. Crustacés amphipodes de surface (Gammare d'eau douce). Association Française de Limnologie, Thonon les Bains, 113p.

Piscart, C., B. J. Kefford \& J. N. Beisel, 2011a. Are salinity tolerances of non-native macroinvertebrates in France an indicator of potential for their translocation in a new area? Limnologica 41: 107 112.

Piscart, C., F. Mermillod-Blondin, C. Maazouzi, S. Merigoux \& P. Marmonier, 2011b. Potential impact of invasive amphipods on leaf litter recycling in aquatic ecosystems. Biological Invasions 13: $2861 \square 2868$.

Platvoet, D., J. T. A. Dick, C. MacNeil, M. C. Van Riel \& G. Van der Velde, 2009a. Invader-invader interactions in relation to environmental heterogeneity leads to zonation of two invasive amphipods, Dikerogammarus villosus (Sowinsky) and Gammarus tigrinus Sexton: amphipod pilot species project (AMPIS) report 6. Biological Invasions 11: 2085[2093.

Platvoet, D., G. Van der Velde, J. T. A. Dick \& S. Li, 2009b. Flexible omnivory in Dikerogammarus villosus (Sowinsky, 1894) (Amphipoda) Amphipod Pilot Species Project (AMPIS) Report 5. Crustaceana 82: 703ロ720. 
Poje, G. V., S. A. Riordan \& J. M. O'Connor, 1988. Food habits of the amphipod Gammarus tigrinus in the Hudson River and the effects of diet upon its growth and reproduction. Fisheries Research in the Hudson River. State University of New York Press, Albany, NY.

Pörtner, H. O., 2002. Climate variations and the physiological basis of temperature dependent biogeography: systemic to molecular hierarchy of thermal tolerance in animals. Comparative Biochemistry and Physiology (A) 132: 739【761.

Posada, D. \& K. A. Crandall, 2001. Selecting the best-fit model of nucleotide substitution. Systematic Biology 50: 580】601.

Rahel, F. J. \& J. D. Olden, 2008. Assessing the effects of climate change on aquatic invasive species. Conservation Biology 22: 521】533.

Ricciardi, A. \& H. J. MacIsaac, 2011. Impacts of Biological Invasions on Freshwater Ecosystems. In: Richardson D. M. (ed.), Fifty Years of Invasion Ecology: The Legacy of Charles Elton, 1st edition, Wiley-Blackwell, Oxford,

Stoffels, B. E. M. W., J. S. Tummers, G. Van der Velde, D. Platvoet, H. W. M. Hendriks\& R. S. E. W. Leuven, 2011. Assessment of predatory ability of native and non-native freshwater gammaridean species: A rapid test with water fleas as prey. Current Zoology 57: 836П843.

Sutcliffe, D. W., 2010. Reproduction in Gammarus (Crustacea: Amphipoda): females strategies. Freshwater Forum 3: $26 \square 64$.

Van der Velde, G., S. Rajagopal, B. Kelleher, I. B. Musko, \& A. Bij de Vaate, 2000. Ecological impact of crustacean invaders: general considerations and examples from the Rhine River. Crustacean Issues 12: $3 \square 34$.

Van der Velde, G., R. S. E. W. Leuven, D. Platvoet, K. Bacela, M. A. J. Huijbregts, H. W. M. Hendriks \& D. Kruijt, 2009. Environmental and morphological factors influencing predatory behaviour by invasive non-indigenous gammaridean species. Biological Invasions 11: 2043[2054. 
498 Wijnhoven, S., M. C. Van Riel \& G. Van der Velde, 2003. Exotic and indigenous freshwater gammarid 499 species: physiological tolerance to water temperature in relation to ionic content of the water. Aquatic Ecology 37: 151】158.

501 Woodward, G., Perkins, D. M., \& L. E. Brown, 2010. Climate change and freshwater ecosystems: impacts across multiple levels of organization. Philosophical Transactions of the Royal Society B: Biological Sciences 365: 2093[2106.

504 


\section{List of figures}

507 Fig. 1 Total quantity of food consumed (mean \pm SE) per mg of gammarid for females (white bars) and males (grey bars) of two invasive gammarids fed on macrophytes, leaf litter and dead chironomid larvae at 15,20 and $25^{\circ} \mathrm{C}$ : (a) Gammarus tigrinus and (b) Dikerogammarus villosus. Different letters indicate significant differences $(p<0.05)$.

Fig. 2 Values (mean \pm SE) of the index of importance (see text for details) of three food types: leaf litter (white bars), macrophytes (light grey bars) and dead chironomid larvae (dark grey bars) consumed by two invasive gammarids at 15, 20 and $25^{\circ} \mathrm{C}$ : (a) Gammarus tigrinus and (b) Dikerogammarus villosus. Different letters indicate significant differences $(p<0.01)$

Fig. 3 Relationship between the number of live water fleas consumed by the two invasive gammarids Gammarus tigrinus (a) and Dikerogammarus villosus (b) and prey density (i.e. the functional response), at three water temperatures: $15^{\circ} \mathrm{C}$ (dots and large-dashed line), $20^{\circ} \mathrm{C}$ (triangles and small-dashed curve) and $25^{\circ} \mathrm{C}$ (squares and full curve). The symbol are direct observations (six replicates per prey density) and the curves are the fits of the theoretical function corresponding (see text for details and Table 1 for 522 the estimates of $a$ and $h$ ).

Fig. 4 Results of the backward and forward stepwise model selection procedure used to compare the functional responses obtained at three different water temperatures for two invasive gammarids, predator searching efficiency and prey handling time, respectively. We considered the simplest model assuming the same parameter values regardless of the temperature (model a,h), the most complex model assuming different parameter values for each temperature (model $\mathrm{a}_{1}, \mathrm{a}_{2}, \mathrm{a}_{3}, \mathrm{~h}_{1}, \mathrm{~h}_{2}, \mathrm{~h}_{3}$ with $1=15^{\circ} \mathrm{C}, 2=20^{\circ} \mathrm{C}$ 
530 and $3=25^{\circ} \mathrm{C}$ ), and all the intermediate models. The numbers above the models are the Akaike criterion

$531\left(\mathrm{AIC}_{\mathrm{c}}\right)$ values. The models selected based on the $\mathrm{AIC}_{\mathrm{c}}$ values are in grey and the best model is in black.

532 Bold arrows show the next model along the procedure and dots indicate the end of the procedure; when

533 the selected model did not perform better that the current model, which becomes the best model. The

534 results of the likelihood ratio tests used to compare current and selected models are on the arrows

535

536 Fig. 5 Confidence regions (grey area) of the estimated parameters (predator searching efficiency $(a)$ and 537 prey handling time $(h)$, see text for details) of the functional response of the two invasive gammarids

538 Gammarus tigrinus (a) and Dikerogammarus villosus (b) feeding on live water fleas at 15,20 and $25^{\circ} \mathrm{C}$ 


\section{List of Tables}

540

541 Table 1 Values of predator searching efficiency $(a)$ and the prey handling time $(h)$ with $95 \%$ 542 confidence intervals estimated for the two invasive gammarids Gammarus tigrinus and 543 Dikerogammarus villosus feeding on water fleas at three water temperatures. The estimates were 544 obtained by fitting the Holling's type II functional response model to the number of prey eaten (see the 545 Materials and Methods section for further details).

\begin{tabular}{cccc}
\hline & Water temperature $\left({ }^{\circ} \mathrm{C}\right)$ & $\begin{array}{c}\text { Predator searching } \\
\text { efficiency }(a)[95 \% \mathrm{CI}]\end{array}$ & $\begin{array}{c}\text { Prey handling time }(h) \\
{[95 \% \mathrm{CI}]}\end{array}$ \\
\hline G. tigrinus & 15 & $0.6313[0.1847 ; 4.7401]$ & $0.4979[0.2327 ; 0.7304]$ \\
20 & $0.6202[0.3580 ; 1.3960]$ & $0.0717[0.0717 ; 0.1315]$ \\
\hline D. villosus & 15 & $20.290[5.3700 ; 269.18]$ & $0.2109[0.1799 ; 0.2404]$ \\
\hline 20 & $1.8920[1.3428 ; 2.7926]$ & $0.1037[0.0868 ; 0.1197]$ \\
& 25 & $2.9434[2.0145 ; 4.1390]$ & $0.0960[0.0839 ; 0.1090]$ \\
& $1.2759[0.8456 ; 1.8611]$ & $0.0690[0.0465 ; 0.0885]$ \\
\hline
\end{tabular}


a) Gammarus tigrinus

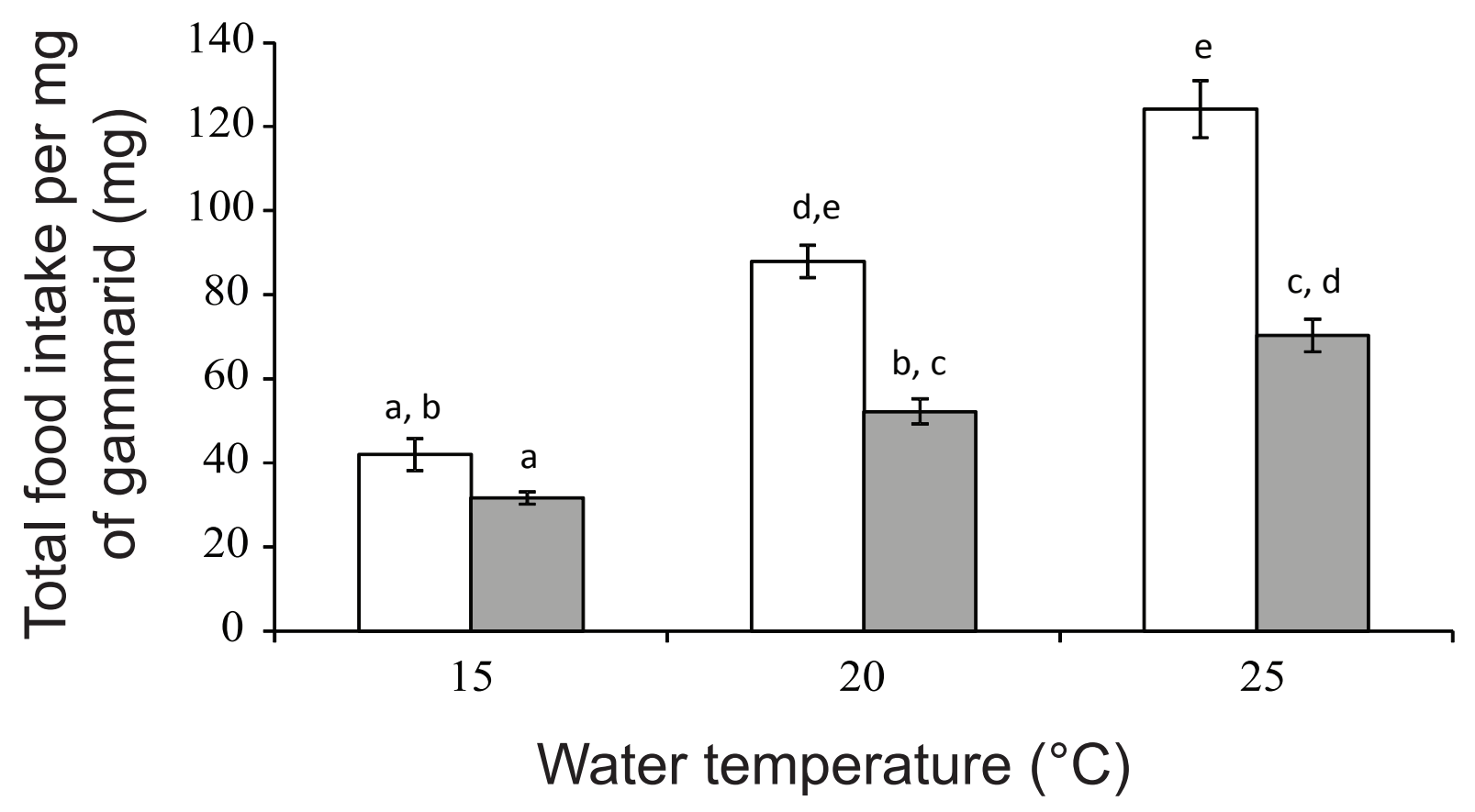

b) Dikerogammarus villosus

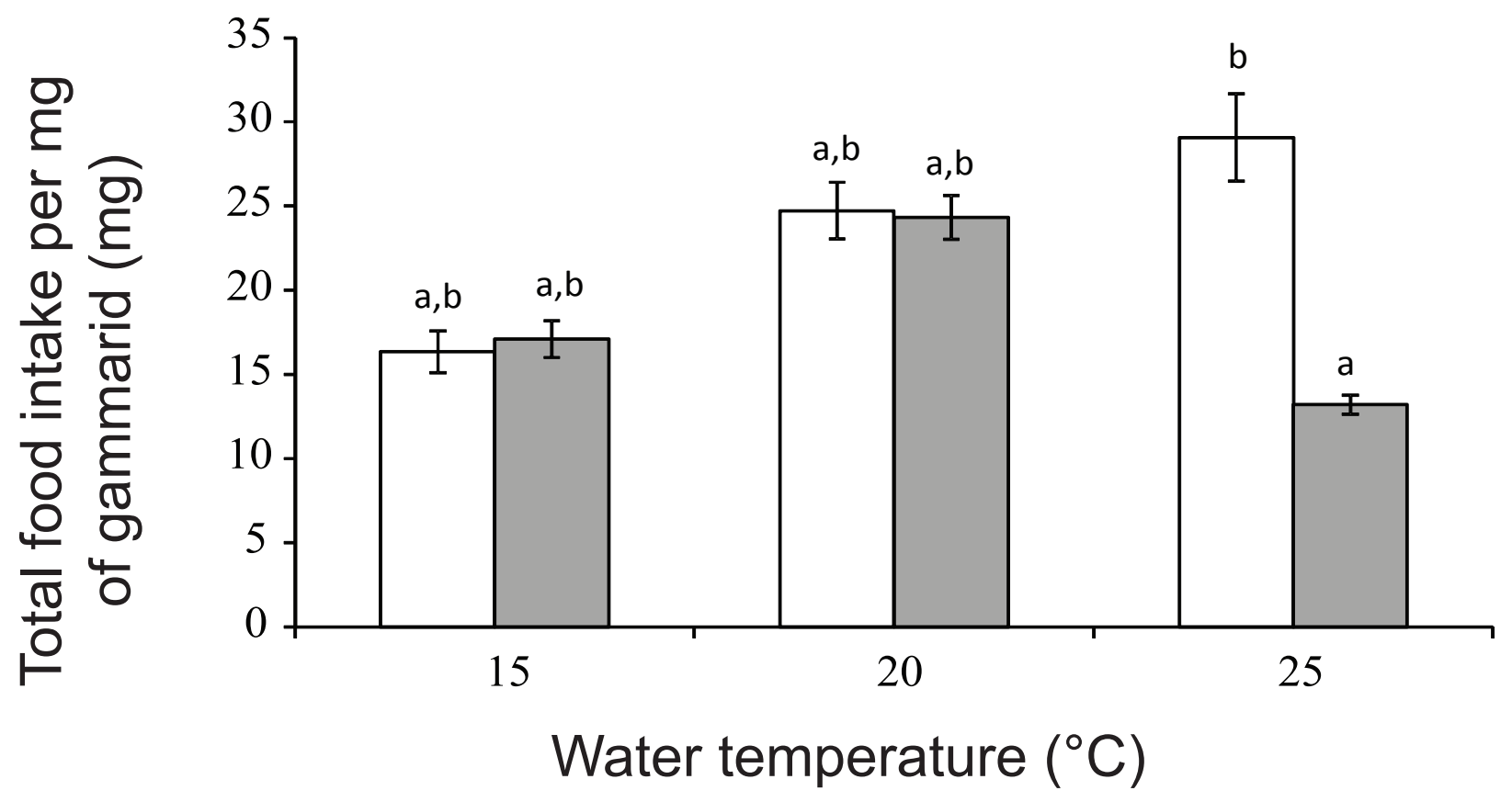



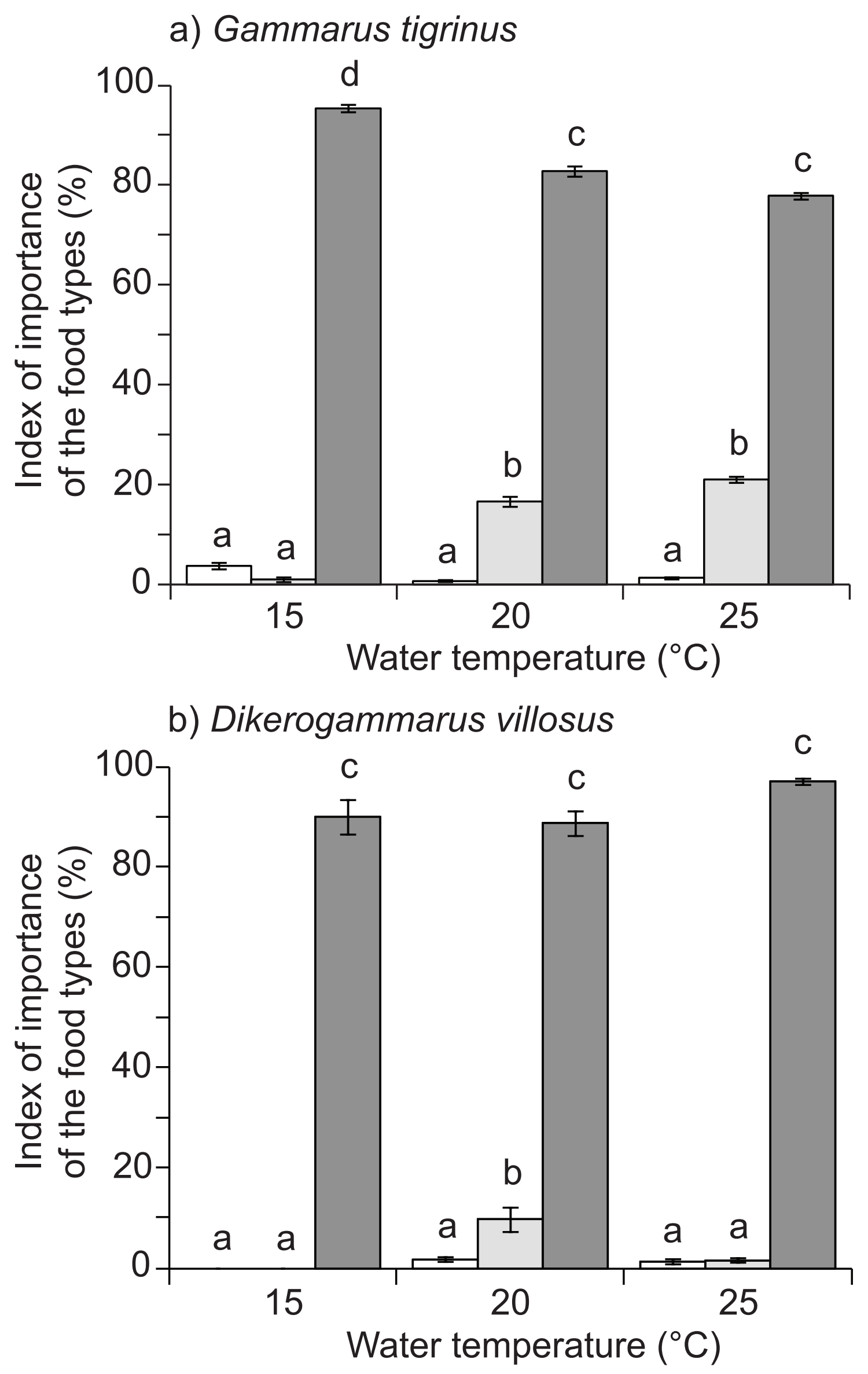


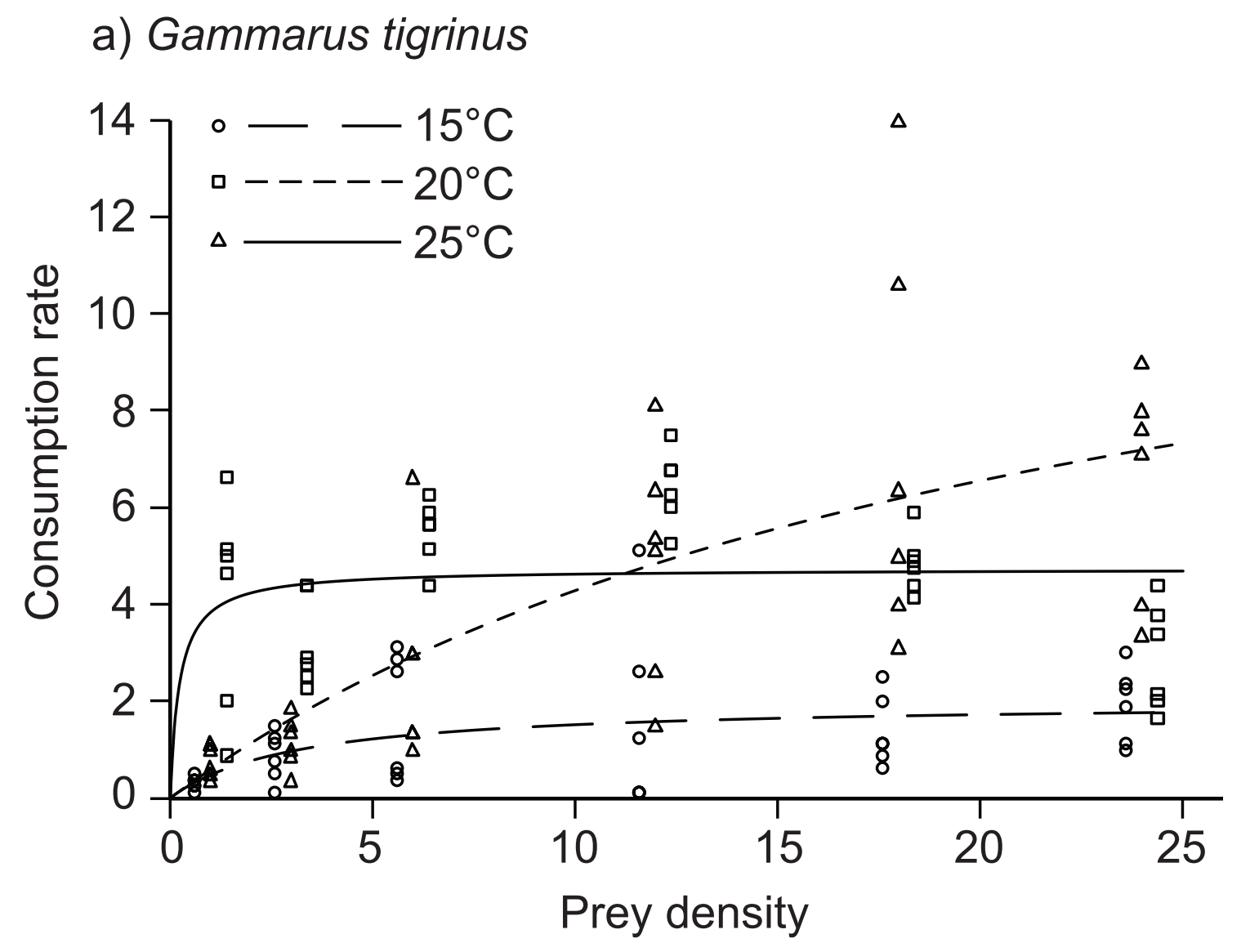

b) Dikerogammarus villosus

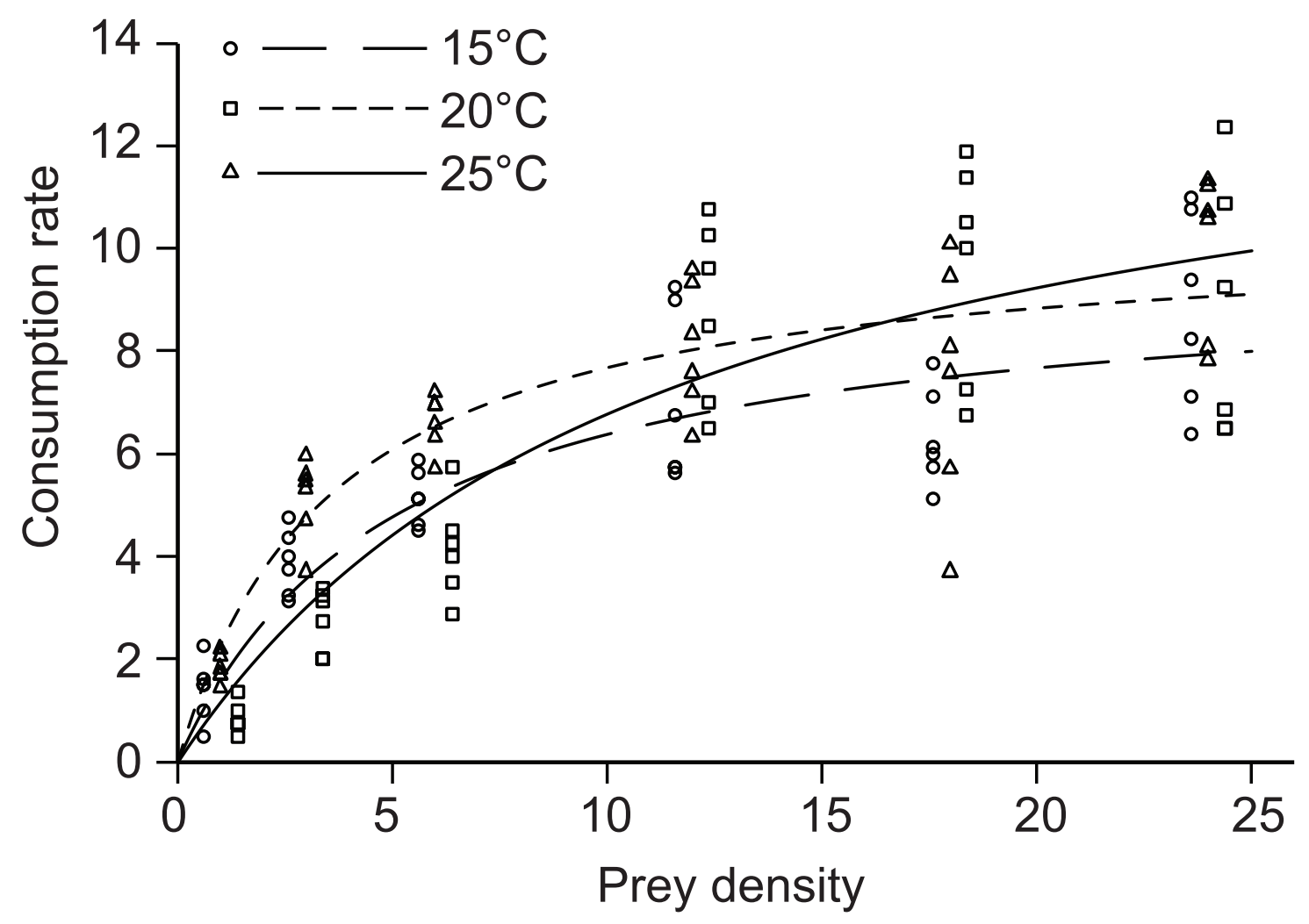


a) Gammarus tigrinus

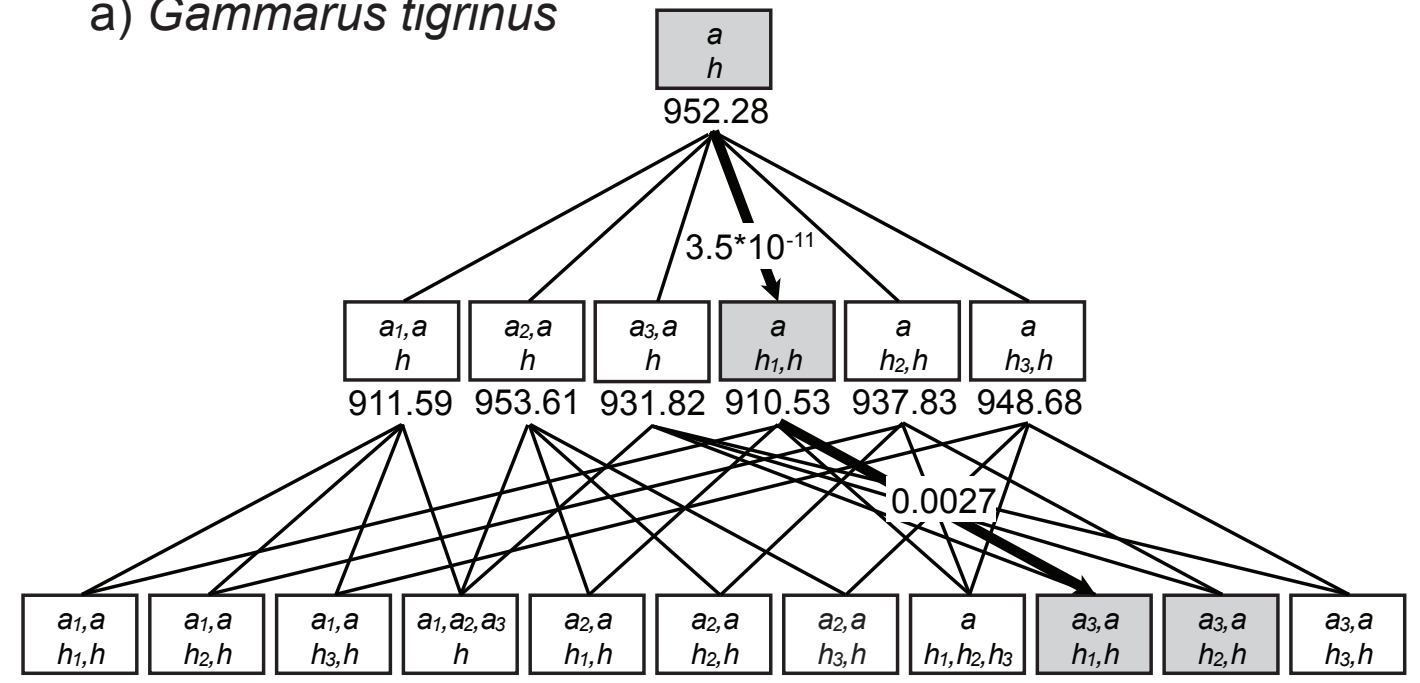

$\begin{array}{lllllllllll}912.01 & 912.36 & 912.53 & 905.04 & 904.93 & 930.28 & 950.78 & 911.22 & 903.69 & 890.71 & 932.20\end{array}$

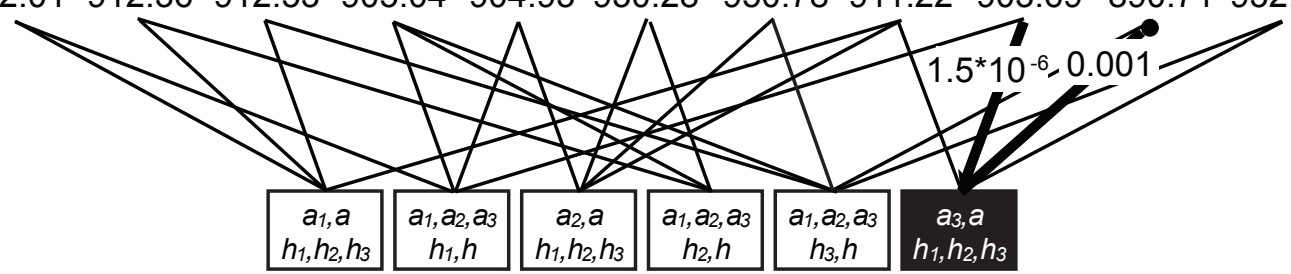

$912.85905 .44885 .38 \quad 884.59885 .74882 .71$

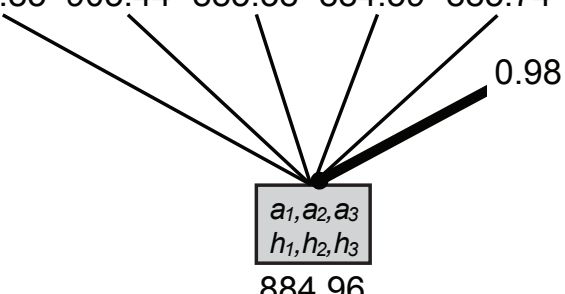

b) Dikerogammarus villosus
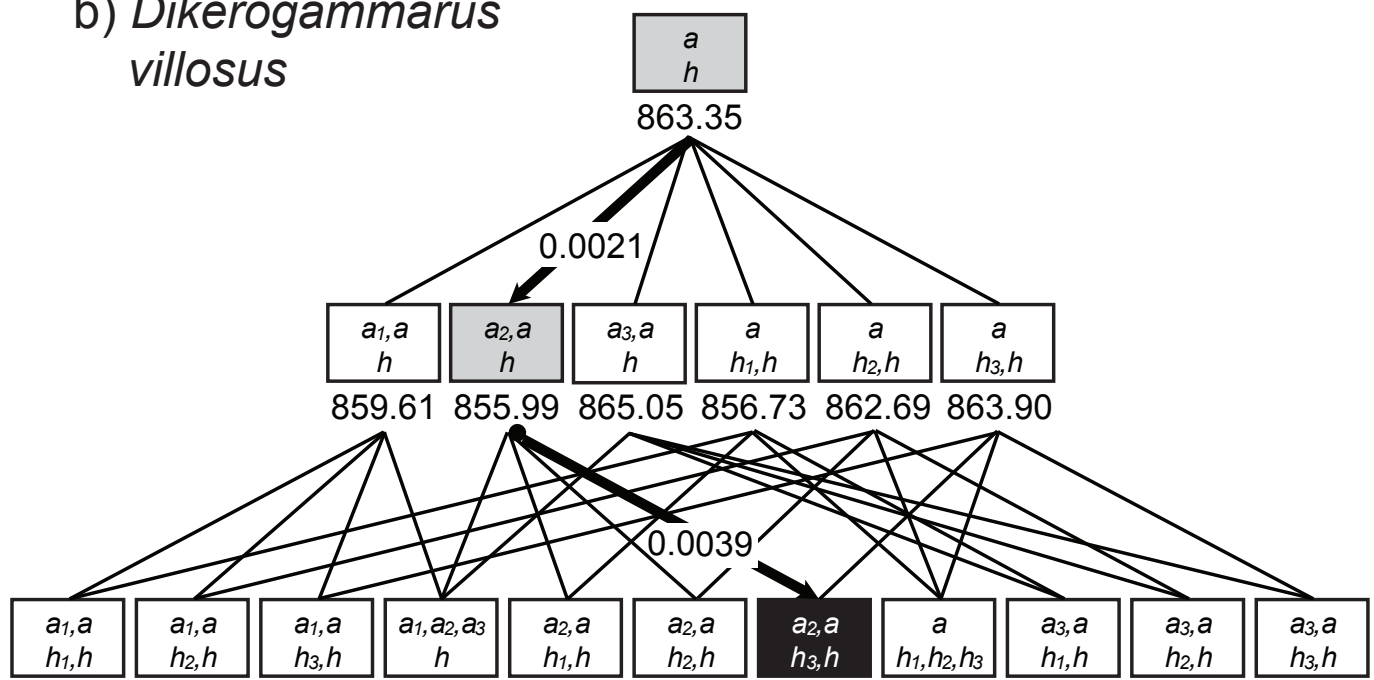

$858.88 \quad 861.26861 .73856 .79854 .57856 .50849 .83858 .84854 .74864 .84858 .34$

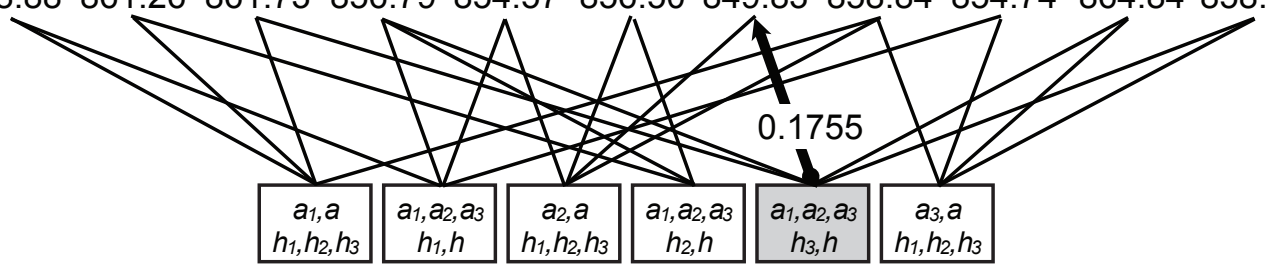

$861.03856 .48 \quad 851.98 \quad 856.72850 .19852 .07$

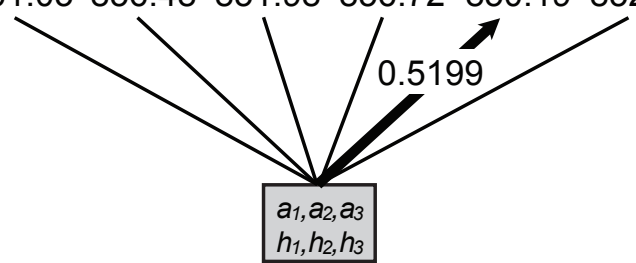

852.05 


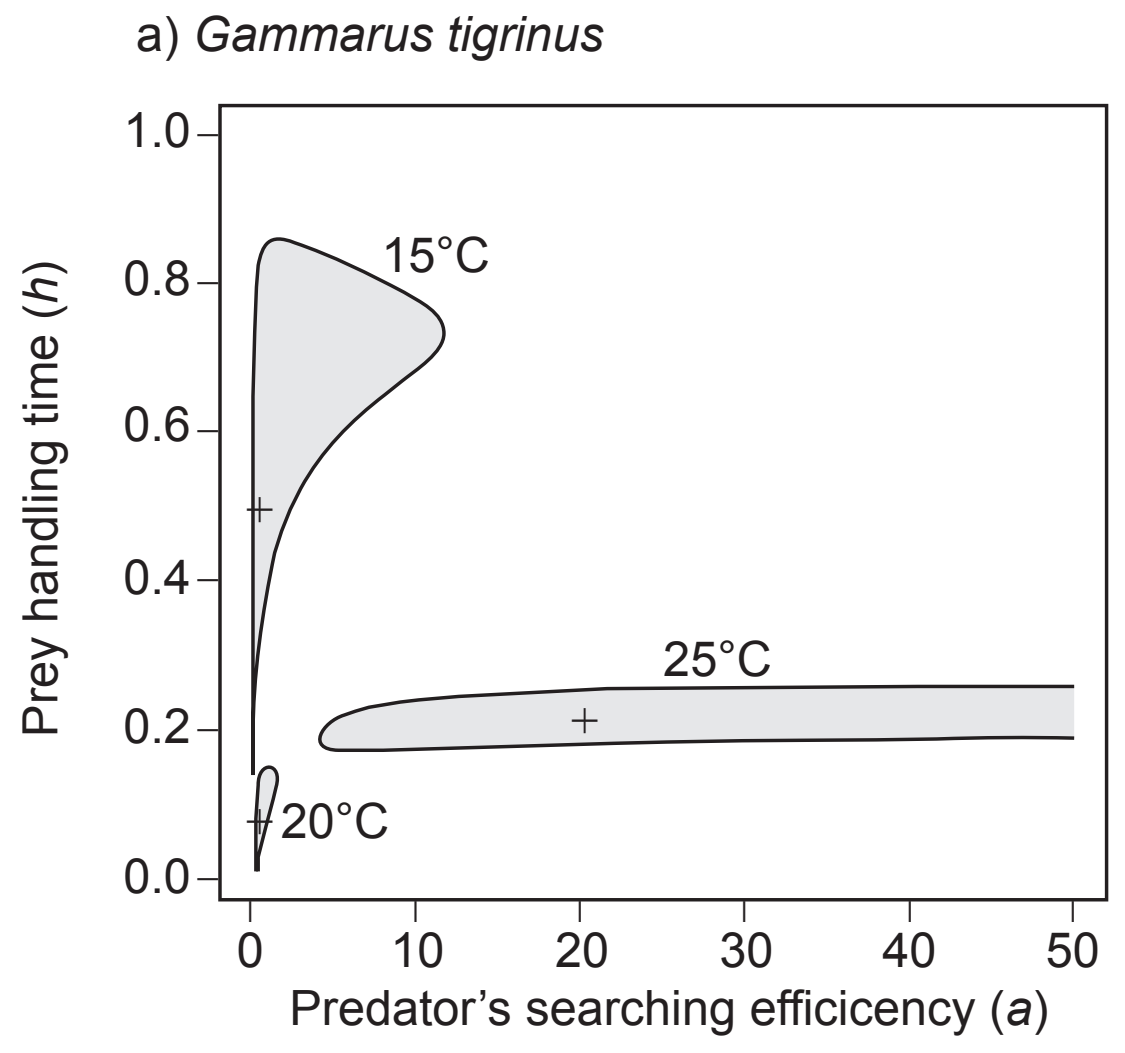

b) Dikerogammarus villosus

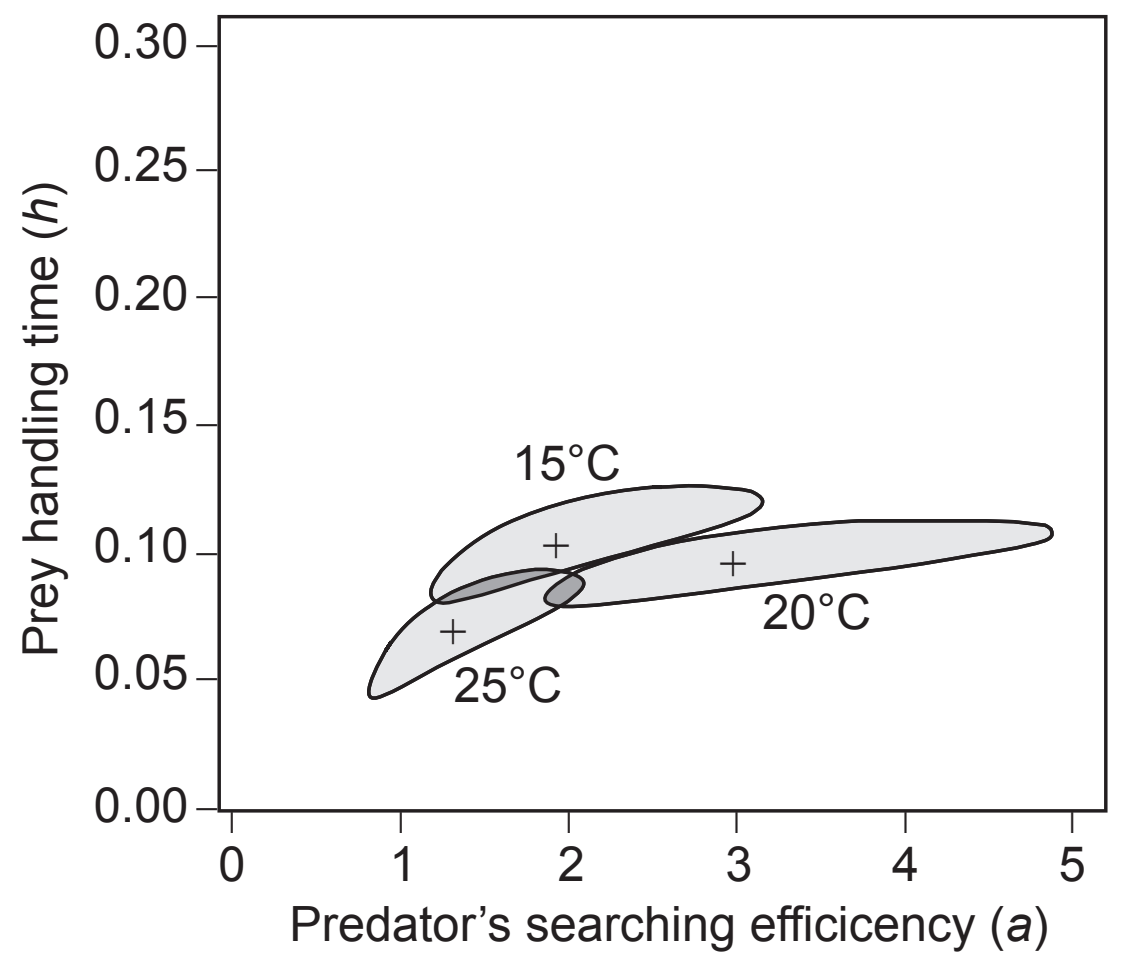

